\title{
800-year ice-core record of nitrogen deposition in Svalbard linked to ocean productivity and biogenic emissions
}

\author{
I. A. Wendl ${ }^{1,2,3}$, A. Eichler ${ }^{1,2}$, E. Isaksson ${ }^{4}$, T. Martma ${ }^{5}$, and M. Schwikowski ${ }^{1,2,3}$ \\ ${ }^{1}$ Laboratory of Radiochemistry and Environmental Chemistry, Paul Scherrer Institut, \\ 5232 Villigen PSI, Switzerland \\ ${ }^{2}$ Oeschger Centre for Climate Change Research, University of Bern, Bern, Switzerland \\ ${ }^{3}$ Department of Chemistry and Biochemistry, University of Bern, Bern, Switzerland \\ ${ }^{4}$ Norwegian Polar Institute, Framsenteret, 9296 Troms $\varnothing$, Norway \\ ${ }^{5}$ Institute of Geology, Tallinn University of Technology, Tallinn, Estonia \\ Correspondence to: M. Schwikowski (margit.schwikowski@psi.ch)
}

Received: 30 July 2014 - Published in Atmos. Chem. Phys. Discuss.: 25 September 2014

Revised: 01 June 2015 - Accepted: 03 June 2015 - Published: 07 July 2015

\begin{abstract}
We present the records of the two nitrogen species nitrate $\left(\mathrm{NO}_{3}^{-}\right)$and ammonium $\left(\mathrm{NH}_{4}^{+}\right)$analysed in a new ice core from Lomonosovfonna, Svalbard, in the Eurasian Arctic covering the period 1222-2009. Changes in melt at the Lomonosovfonna glacier are assumed to have a negligible effect on the decadal variations of the investigated compounds. Accordingly, we use decadal records to investigate the major emission sources of $\mathrm{NO}_{3}^{-}$and $\mathrm{NH}_{4}^{+}$precursors and find that during the twentieth century both records are influenced by anthropogenic pollution from Eurasia. In pre-industrial times $\mathrm{NO}_{3}^{-}$is highly correlated with methane sulfonate (MSA), which we explain by a fertilising effect. We propose that enhanced atmospheric $\mathrm{NO}_{3}^{-}$concentrations and the corresponding nitrogen input to the ocean trigger the growth of dimethyl-sulfide-(DMS)-producing phytoplankton. Increased DMS production results in elevated fluxes to the atmosphere where it is oxidised to MSA. Eurasia was presumably the main source area also of pre-industrial $\mathrm{NO}_{3}^{-}$, but a more exact source apportionment could not be performed based on our data. This is different for $\mathrm{NH}_{4}^{+}$, where biogenic ammonia $\left(\mathrm{NH}_{3}\right)$ emissions from Siberian boreal forests were identified as the dominant source of pre-industrial $\mathrm{NH}_{4}^{+}$.
\end{abstract}

\section{Introduction}

The Arctic is generally a nutrient limited region (Dickerson, 1985). Nutrients originate from lower latitudes and reach the remote polar areas via long-range transport; local sources are sparse. The major source of bio-available nitrogen in the Arctic is the deposition of reactive atmospheric nitrogen that is present primarily as nitrate $\left(\mathrm{NO}_{3}^{-}\right)$and ammonium $\left(\mathrm{NH}_{4}^{+}\right)$ (Björkman et al., 2013; Kühnel et al., 2011). Those species are predominantly removed from the atmosphere by wet deposition (Bergin et al., 1995). $\mathrm{NO}_{3}^{-}$is the oxidation product of emitted $\mathrm{NO}_{x}\left(\mathrm{NO}\right.$ and $\left.\mathrm{NO}_{2}\right)$. At a global scale, major $\mathrm{NO}_{3}^{-}$sources include biomass burning, emissions from microbial processes in soils, ammonia oxidation, stratospheric injection, lightning, as well as fossil fuel and biofuel combustion, and aircraft emissions (Fibiger et al., 2013; Galloway et al., 2004; Hastings et al., 2004; Wolff, 2013). $\mathrm{NH}_{4}^{+}$derives from biogenic emissions of ammonia $\left(\mathrm{NH}_{3}\right)$ from terrestrial and marine sources, biomass burning, agriculture, and livestock breeding (Fuhrer et al., 1996; Galloway et al., 2004; Wolff, 2013). Both $\mathrm{NO}_{3}^{-}$and $\mathrm{NH}_{4}^{+}$concentrations in the atmosphere have varied greatly with time and space due to changing emissions and the short atmospheric lifetimes of a few days (Adams et al., 1999; Feng and Penner, 2007). Generally, concentrations were low in pre-industrial times and increased due to stronger emissions with the beginning of the industrialisation and intensification of agricultural activities (Galloway et al., 2004). The deposition of $\mathrm{NO}_{3}^{-}$and $\mathrm{NH}_{4}^{+}$in 


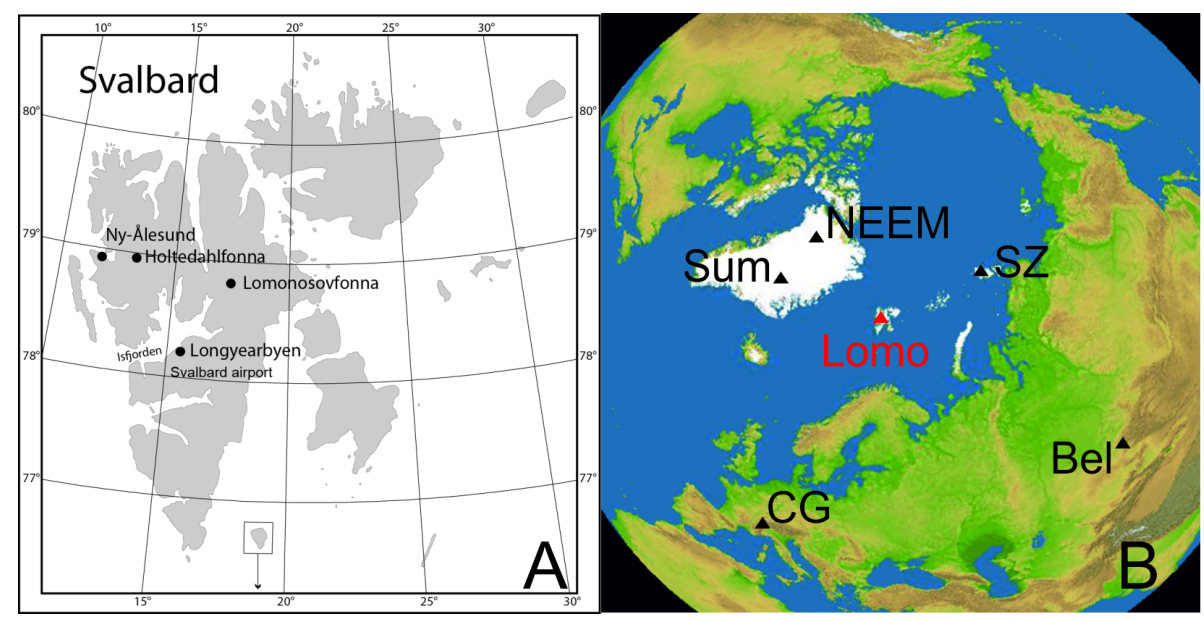

Figure 1. (a) Map of Svalbard with the locations of Lomonosovfonna and Holtedahlfonna. (b) Map with all ice-core locations discussed in the text: Lomo: Lomonosovfonna (red triangle); NEEM; Sum: Summit; SZ: Severnaya Zemlya; Bel: Belukha; and CG: Colle Gnifetti (black triangles). Satellite image in (b) PlanetObserver ${ }^{\circledR}$, extracted from DVD-ROM "Der Große 3-D-Globus 4.0 Premium", \# 2008 United Soft Media Verlag GmbH, Munich.

the Arctic is an important nutrient source. Varying concentrations thus greatly affect the nitrogen budget in the Arctic, where nutrient supply is limited.

Ice cores represent an invaluable archive of past atmospheric composition. Ice-core studies from the Arctic clearly reveal an anthropogenic influence on the concentrations of $\mathrm{NO}_{3}^{-}$and $\mathrm{NH}_{4}^{+}$approximately during the last 150 years (Fischer et al., 1998; Fuhrer et al., 1996; Goto-Azuma and Koerner, 2001; Kekonen et al., 2002, 2005; Legrand and Mayewski, 1997; Matoba et al., 2002; Simões and Zagorodnov, 2001). North America was identified as a major pollutant source for southern Greenland, both North America and Eurasia for central and northern Greenland, and Eurasia for Svalbard (Goto-Azuma and Koerner, 2001; Hicks and Isaksson, 2006). However, the pre-industrial sources of $\mathrm{NO}_{3}^{-}$ and $\mathrm{NH}_{4}^{+}$are still fairly unknown (Legrand and Mayewski, 1997; Wolff, 2013). Eichler et al. (2011) identified forest fires as a major source of $\mathrm{NO}_{3}^{-}$in a Siberian Altai ice core from the mid-latitudes. In studies on Greenland ice, $\mathrm{NO}_{3}^{-}$ was also associated with forest fires (Whitlow et al., 1994; Wolff et al., 2008). Pre-industrial $\mathrm{NH}_{4}^{+}$in ice cores from the mid-latitudes was attributed to biogenic emissions (Eichler et al., 2009; Kellerhals et al., 2010). Similarly, long-term trends in Greenland ice cores have been attributed to changing biogenic emission from North America, whereas shortterm $\mathrm{NH}_{4}^{+}$changes were found to correlate with forest fires (Fuhrer et al., 1996; Whitlow et al., 1994; Zennaro et al., 2014).

Whereas a few records exist from Greenland, there is less information available from the Eurasian Arctic. The $\mathrm{NO}_{3}^{-}$ and $\mathrm{NH}_{4}^{+}$records of a previous ice core from Lomonosovfonna, Svalbard, retrieved in 1997 (Lomo97; for the location, see Fig. 1), cover the last 1000 years (Divine et al., 2011;
Kekonen et al., 2002, 2005). For both species a clear anthropogenic impact is observed in the second half of the twentieth century, but the pre-industrial sources remain largely unidentified due to potential runoff that biased the ion records before the mid-sixteenth century (Kekonen et al., 2002, 2005). Nevertheless, the fairly stable concentrations in the $\mathrm{NO}_{3}^{-}$ record from the mid-sixteenth to the mid-nineteenth century are interpreted as input from natural $\mathrm{NO}_{3}^{-}$sources (Kekonen et al., 2002). An anthropogenic influence in the twentieth century is also visible in the $\mathrm{NO}_{3}^{-}$and $\mathrm{NH}_{4}^{+}$records of other Eurasian Arctic ice cores (see Fig. 1 for locations) from Holtedahlfonna (Holte05), Svalbard (Beaudon et al., 2013), Snøfjellafonna, Svalbard (Goto-Azuma and Koerner, 2001), and Severnaya Zemlya (Weiler et al., 2005). The industrial records from these cores are discussed in detail, but preindustrial sources and concentration changes of the inorganic nitrogen species remain unexplained.

The interpretation of $\mathrm{NO}_{3}^{-}$and $\mathrm{NH}_{4}^{+}$as paleoenvironmental proxies may be hampered by the fact that both undergo post-depositional processes leading to loss from or relocation within the snowpack even at temperatures well below the melting point (Pohjola et al., 2002). $\mathrm{NO}_{3}^{-}$can be relocated or lost by photolysis and/or evaporation of nitric acid $\left(\mathrm{HNO}_{3}\right)$ (Honrath et al., 1999; Röthlisberger et al., 2002). This loss can be severe at low accumulation sites such as Dome C, Antarctica (Röthlisberger et al., 2000, 2002). At sites with higher accumulation rates such as Summit in Greenland or Weissfluhjoch in the European Alps, the majority of $\mathrm{NO}_{3}^{-}$is preserved (Baltensperger et al., 1993; Fibiger et al., 2013). Many studies reveal that $\mathrm{NH}_{4}^{+}$and $\mathrm{NO}_{3}^{-}$are preserved in snow and firn cores with respect to percolating meltwater (Eichler et al., 2001; Ginot et al., 2010; Moore and Grinsted, 2009; Pohjola et al., 2002), but others report a preferential elution of these species compared to other major ions (Brim- 
blecombe et al., 1985; Moore and Grinsted, 2009; Pohjola et al., 2002). The underlying mechanism is not well understood, except from the fact that it depends on the overall ion composition.

In this paper we discuss the records of the two nitrogen species $\mathrm{NO}_{3}^{-}$and $\mathrm{NH}_{4}^{+}$analysed in a new ice core drilled on Lomonosovfonna, Svalbard, in 2009. The study focuses on the investigation of the major sources of $\mathrm{NO}_{3}^{-}$and $\mathrm{NH}_{4}^{+}$ deposited in the Eurasian Arctic which highly affects the nutrient budget in the region, along with the effect of melt on the geochemical records of these nitrogen species which will gain importance due to the ongoing global warming.

\section{Methods}

\subsection{Drilling site and meteorological setting}

In 2009, a $149.5 \mathrm{~m}$ long ice core was drilled on Lomonosovfonna, Svalbard (1202 m a.s.1.; $78^{\circ} 49^{\prime} 24^{\prime \prime} \mathrm{N}, 17^{\circ} 25^{\prime} 59^{\prime \prime} \mathrm{E}$, Lomo09), using the Fast Electromechanical Lightweight Ice Coring System (FELICS) (Ginot et al., 2002). The 2009 drilling site is $4.6 \mathrm{~km}$ south of that in 1997 (Lomo97) (Isaksson et al., 2001). Bedrock was not reached, but a radar survey suggested it to be at around $200 \mathrm{~m}$ (Pettersson, unpublished data). Measured borehole temperatures in the upper $42 \mathrm{~m}$ (between -1.7 and $-4.3^{\circ} \mathrm{C}$ ) at the Lomo09 drill site are in good agreement with the average borehole temperature at the Lomo97 site of $-2.8^{\circ} \mathrm{C}$ with a nearly isothermal profile (Van de Wal et al., 2002). Previous studies indicate that summer meltwater in the study area is refrozen mostly within the previous winter's snow, and the remainder within the next two to three lower annual layers (Samuelson, 2001). Percolation length was found to be up to 8 years only in the warmest years during the twentieth century (Kekonen et al., 2005; Moore et al., 2005).

Svalbard is located at a climatically sensitive area, being surrounded by the Arctic Ocean, the Barents Sea and the Atlantic Ocean, and situated at the southerly edge of the permanent Arctic sea ice and close to the over-turning point of the North Atlantic thermohaline circulation. Furthermore, it is relatively close to the industrialised areas of Eurasia which were found to highly affect the chemical composition of air reaching the archipelago, especially in spring during the Arctic haze (Eleftheriadis et al., 2009; Eneroth et al., 2003; Forsström et al., 2009; Goto-Azuma and Koerner, 2001; Law and Stohl, 2007; Stohl et al., 2007). The Arctic haze describes a phenomenon of increased aerosol concentration in the end of winter to early spring (Greenaway, 1950; Quinn et al., 2007; Shaw, 1995). At that time of the year, temperatures in the Arctic become very low, which leads to a thermally very stable stratification with strong surface inversions (Shaw, 1995; Stohl, 2006). This cold stratified air forms a dome over the Arctic that hinders warm air masses from lower latitudes from entering. The boundary of

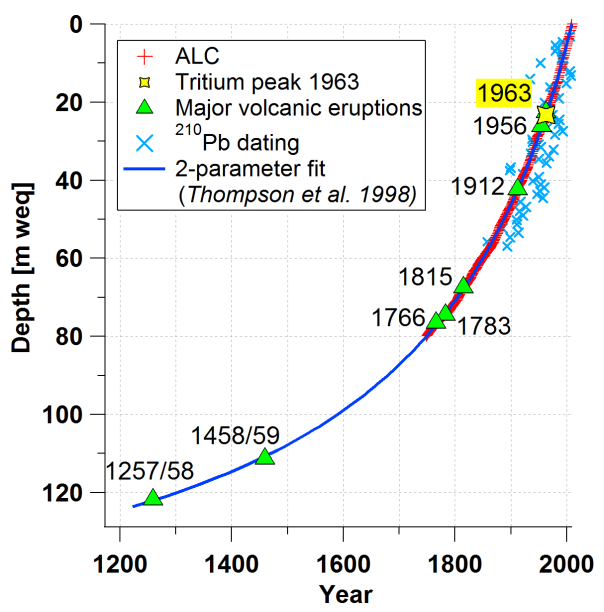

Figure 2. Depth-age relationship of the Lomo09 ice core showing all dating methods applied. Depth is given in $\mathrm{m}$ weq to account for density variation.

this dome that acts as a transport barrier is called Arctic or Polar front whose position shifts between summer and winter due to temperature. In summer, only the more northern parts of the Northern Hemisphere are cold enough to cause a stable stratification of the atmosphere, whereas in winter temperatures in more southern parts are cold enough so that the Arctic or Polar front is located as far south as $40^{\circ} \mathrm{N}$. Then large areas of Eurasia and, partly, North America are included in the Arctic dome, facilitating transport of pollution from those regions. In addition, since both dry and wet deposition is reduced within the Arctic dome in winter, aerosolrelated species have very long lifetimes once within the Arctic dome (Stohl, 2006).

\subsection{Sampling and analyses}

The Lomonosovfonna 2009 ice core was processed in the cold room $\left(-20^{\circ} \mathrm{C}\right)$ at the Paul Scherrer Institut, Switzerland, resulting in 3997 samples with a depth resolution of 3 $4 \mathrm{~cm}$ (details on the method in Eichler et al., 2000). The resolution was adapted to layer thinning with depth, so that even in the deepest and oldest part of the core, each year is at least represented by one sample. The inner part of the core was sampled for the analysis of water soluble major ions and the water stable isotopes $\delta^{18} \mathrm{O}$ and $\delta \mathrm{D}$. Outer core sections were analysed for ${ }^{3} \mathrm{H}$ and ${ }^{210} \mathrm{~Pb}$ used for dating purposes (Eichler et al., 2000).

Concentrations of water soluble major ions, including $\mathrm{NO}_{3}^{-}$and $\mathrm{NH}_{4}^{+}$, were determined using ion chromatography (Metrohm 850 Professional IC combined with a 872 Extension Module and a 858 Professional Sample Processor autosampler). Prior to analyses, ice samples were melted in a $\mathrm{N}_{2}$ atmosphere to reduce contamination from laboratory air. A list of the measured ionic species, their detection limits and median concentrations is given in Table 1. 
Table 1. Detection limits and median values $\left(\mu \mathrm{eq} \mathrm{L}^{-1}\right)$ for the ions analysed with the Metrohm 850 Professional IC. Pre-ind.: pre-industrial time from 1222 to 1859; Ind.: industrial time from 1860 to 2009; $\mathrm{MSA}: \mathrm{CH}_{3} \mathrm{SO}_{3}^{-}$.

\begin{tabular}{|c|c|c|c|c|c|c|c|}
\hline \multirow[t]{3}{*}{ Anions } & \multirow{3}{*}{$\begin{array}{r}\text { Detection } \\
\text { limit }\end{array}$} & & & \multirow[t]{3}{*}{ Cations } & \multirow{3}{*}{$\begin{array}{r}\text { Detection } \\
\text { limit }\end{array}$} & \multirow{2}{*}{\multicolumn{2}{|c|}{ Median }} \\
\hline & & \multicolumn{2}{|c|}{ Median } & & & & \\
\hline & & Pre-ind. & Ind. & & & Pre-ind. & Ind. \\
\hline MSA & 0.005 & 0.09 & 0.05 & $\mathrm{Na}^{+}$ & 0.02 & 8.77 & 7.18 \\
\hline $\mathrm{Cl}^{-}$ & 0.02 & 10.48 & 8.92 & $\mathrm{NH}_{4}^{+}$ & 0.02 & 0.50 & 0.74 \\
\hline $\mathrm{NO}_{3}^{-}$ & 0.01 & 0.54 & 0.65 & $\mathrm{~K}^{+}{ }^{4}$ & 0.02 & 0.25 & 0.19 \\
\hline \multirow[t]{2}{*}{$\mathrm{SO}_{4}^{2-}$} & 0.02 & 2.08 & 2.63 & $\mathrm{Mg}^{2+}$ & 0.03 & 2.10 & 1.32 \\
\hline & & & & $\mathrm{Ca}^{2+}$ & 0.04 & 1.43 & 1.02 \\
\hline
\end{tabular}
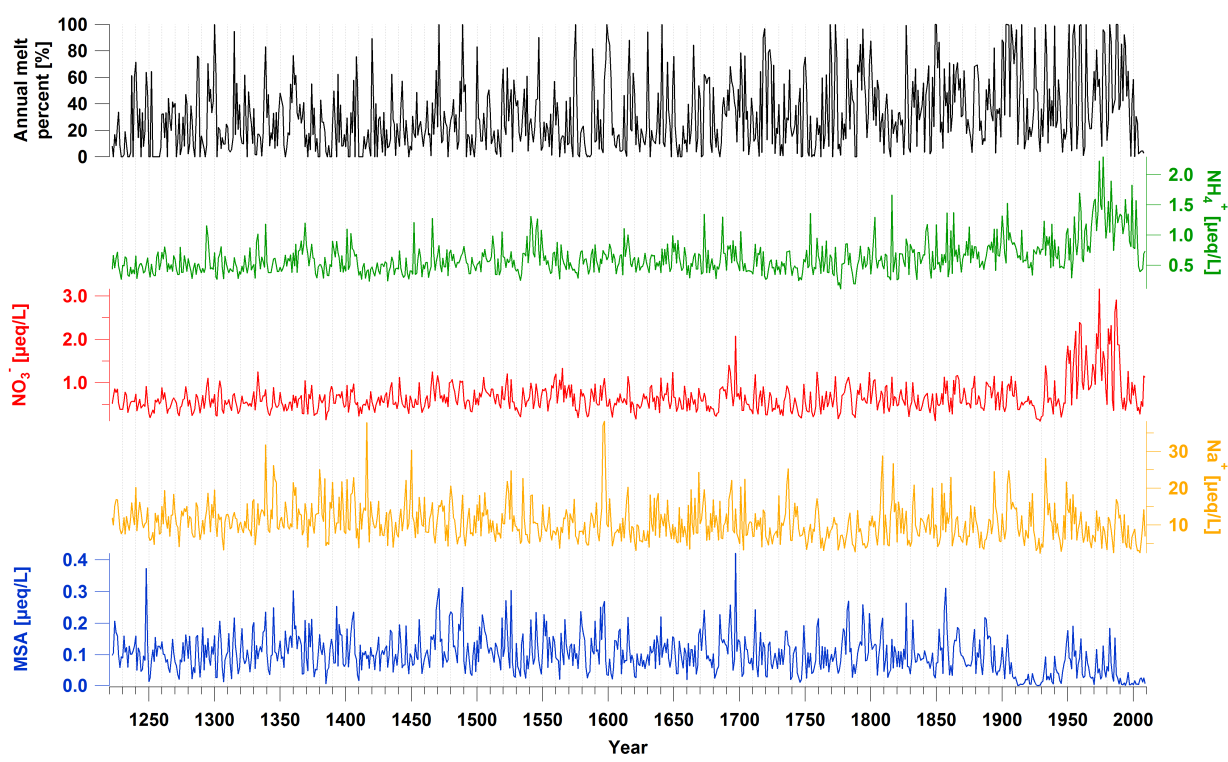

Figure 3. Temporal records of annual average concentrations of $\mathrm{MSA}, \mathrm{Na}^{+}, \mathrm{NO}_{3}^{-}$and $\mathrm{NH}_{4}^{+}$and annual melt percent of the Lomo09 ice core.

\subsection{Ice-core dating}

The Lomo09 ice core covers the time period of 1222 to 2009 (Fig. 2). It was dated with a combination of reference horizons, annual layer counting (ALC), ${ }^{210} \mathrm{~Pb}$ decay, and a simple glacier flow model. The reference horizons include the tritium peak indicating the year 1963, and the major volcanic eruptions of Bezymianny (1956), Katmai (1912), Tambora (1815), Laki (1783), Hekla (1766), Kuwae (1458/59; Sigl et al., 2013), and Samalas (1257/58; Lavigne et al., 2013) marked by high non-sea-salt sulfate concentrations and high values for the sulfate residual of the multiple linear regression of all measured ions, a method previously described in Moore et al. (2012). Annual layer counting was performed down to a depth of $\sim 79.7 \mathrm{~m}$ weq $(=1750)$ using the pronounced seasonality of $\delta^{18} \mathrm{O}$ and $\mathrm{Na}^{+}$(Fig. S1 in the Supplement). A simple glacier flow model (Thompson et al., 1998) was fitted through the volcanic reference horizons.
This was used to date the core below $\sim 79.7 \mathrm{~m}$ weq where ALC was limited due to strong layer thinning. The dating uncertainty for the core down to a depth of $\sim 68 \mathrm{~m}$ weq is estimated to be \pm 1 year within \pm 10 years of the reference horizons and increases to \pm 3 years in between. Down to a depth of $\sim 80 \mathrm{~m}$ weq the dating uncertainty enlarges to \pm 3 years also in the proximity of the reference horizons, and below $\sim 80 \mathrm{~m}$ weq it increases to \pm 10 years. This was calculated using the difference of the year of the volcanic eruptions and the modelled date. The average annual accumulation rate is $0.58 \pm 0.13 \mathrm{~m}$ weq.

\subsection{Calculation of annual melt percent}

Melt features are formed when surface snow melts and the meltwater percolates into deeper layers where it fills the pores and refreezes under the formation of a layer of ice poor in or free of air bubbles. The percentage of annual melt in the Lomo09 core was calculated from the thickness of melt fea- 


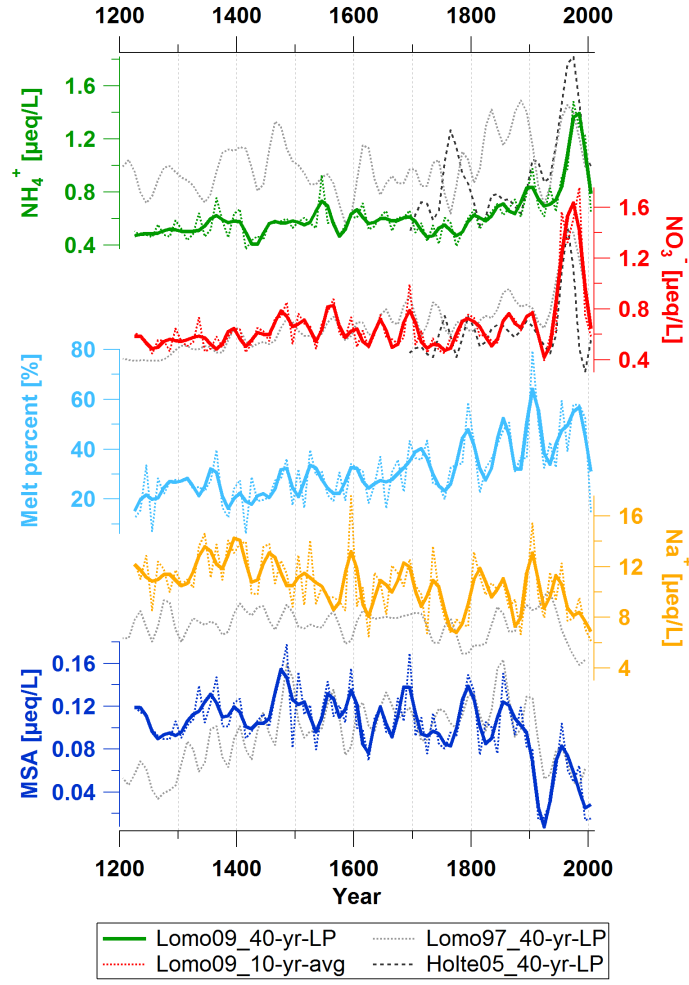

Figure 4. Records of $\mathrm{NH}_{4}^{+}$(green), $\mathrm{NO}_{3}^{-}$(red), melt percent (light blue), $\mathrm{Na}^{+}$(yellow), and MSA (dark blue) of the Lomo09 ice core. Bold lines are 40-year low-pass-filtered (40-yr-LP); dashed lines are 10 -year averages (10-yr-avg). Raw data are available in the Supplement (Figs. S2 and S3). Grey dashed lines are 40-year low-passfiltered records of $\mathrm{NH}_{4}^{+}, \mathrm{NO}_{3}^{-}, \mathrm{Na}^{+}$, and MSA of the Lomo97 ice core (Kekonen et al., 2005) calculated with the updated chronology of Divine et al. (2011). Black dashed lines are 40-year low-passfiltered records of $\mathrm{NH}_{4}^{+}$and $\mathrm{NO}_{3}^{-}$of the Holte05 ice core (Beaudon et al., 2013).

tures observed during processing of the core (similar to Henderson et al., 2006). Clear and bubbly ice appears as transparent area when the core is backlit. If the melt did not affect the whole core diameter, this was accounted for by multiplying the length of the melt feature with the percentage of the core diameter it covered. If for example a melt feature was $20 \mathrm{~cm}$ long but only affected one-fifth of the core diameter, this melt feature would count the same as a $4 \mathrm{~cm}$ long melt feature affecting the whole core diameter. The observed melt features were then summed up per year to calculate the annual melt percent (Fig. 3).

\section{Results and discussion}

The records of $\mathrm{NO}_{3}^{-}$and $\mathrm{NH}_{4}^{+}$of the Lomo09 core both show the highest concentrations during the period of approximately 1940 to 1980 (Figs. 3 and 4), similar to findings from other Arctic sites (Goto-Azuma and Koerner, 2001).

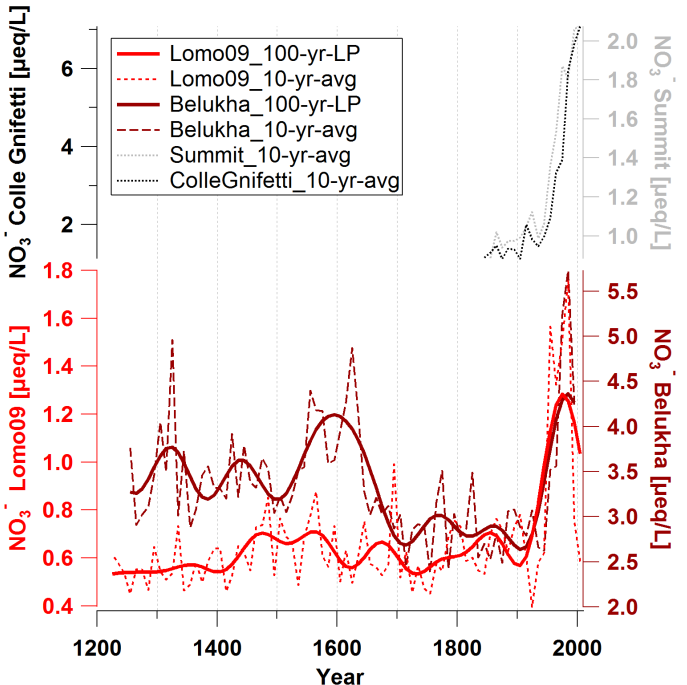

Figure 5. $\mathrm{NO}_{3}^{-}$records from Lomo09 (red), Belukha (dark red; Eichler et al., 2009), Summit, Greenland (grey; Geng et al., 2014), and Colle Gnifetti, Swiss Alps (black; Sigl, 2009). Bold lines are 100-year low-pass-filtered (100-yr-LP); dashed lines are 10-year averages (10-yr-avg).

This clearly indicates a strong influence of anthropogenic emissions in recent decades on the chemical composition of aerosols reaching Lomonosovfonna. Both records show a significant decrease after 1980, a trend similarly observed in the $\mathrm{NO}_{3}^{-}$and $\mathrm{NH}_{4}^{+}$records of ice cores from the Siberian Altai (Eichler et al., 2009, 2011) (Fig. 5) and Severnaya Zemlya (Opel et al., 2013; Weiler et al., 2005) influenced mainly by Eurasian pollution. The Siberian Altai core ends in 2001 , explaining why the continuation of the decrease seen at Lomonosovfonna is not recorded there. The nitrate trend in the Siberian Altai fits well with $\mathrm{NO}_{x}$ emissions as discussed in detail in Eichler et al. (2009), where the eastern European $\mathrm{NO}_{x}$ emissions are shown. In contrast, $\mathrm{NO}_{3}^{-}$concentrations in records from Summit, Greenland, and Colle Gnifetti, Swiss Alps (see Fig. 1 for locations), affected by North American and western European air masses, respectively, kept rising into the twenty-first century (Fig. 5). This suggests that the major sources of the increased concentrations of $\mathrm{NO}_{3}^{-}$and $\mathrm{NH}_{4}^{+}$in the Lomo09 core are similar to those for the Siberian Altai and Severnaya Zemlya, whereas the influence of emissions in North America and Europe is of minor importance. Our finding is in agreement with results from transport modelling and trajectory analysis, identifying Eurasia as a source region for Svalbard (Hirdman et al., 2010a, b). Eurasian pollution dominates especially during the autumn and winter periods characterised by Arctic haze episodes, in contrast to summer months when North Atlantic air masses prevail (Tunved et al., 2013). We thus attribute the observed trend after 1940 in $\mathrm{NO}_{3}^{-}$to higher $\mathrm{NO}_{x}$ emissions from traffic, energy production, and industrial activities, and 
Table 2. Results of the principal component analysis (PCA) after VARIMAX rotation. Time period: 1222-1859; data: 10-year averages; MSA: $\mathrm{CH}_{3} \mathrm{SO}_{3}^{-}$; melt \%: melt percent. Values $>0.8$ marked in bold.

\begin{tabular}{lrrrrrr}
\hline & PC1 & PC2 & PC3 & PC4 & PC5 & PC6 \\
\hline $\mathrm{Na}^{+}$ & $\mathbf{0 . 9 7}$ & 0.06 & 0.05 & 0.11 & -0.03 & 0.08 \\
$\mathrm{~K}^{+}$ & $\mathbf{0 . 8 8}$ & 0.18 & 0.00 & -0.04 & -0.07 & 0.16 \\
$\mathrm{Mg}^{2+}$ & $\mathbf{0 . 8 2}$ & 0.37 & 0.02 & 0.27 & 0.07 & 0.19 \\
$\mathrm{Cl}^{-}$ & $\mathbf{0 . 9 7}$ & 0.08 & 0.06 & 0.12 & 0.01 & 0.08 \\
$\mathrm{MSA}^{-}$ & 0.33 & $\mathbf{0 . 8 0}$ & 0.13 & 0.22 & 0.23 & 0.11 \\
$\mathrm{NO}_{3}^{-}$ & 0.11 & $\mathbf{0 . 8 9}$ & 0.22 & 0.16 & 0.09 & 0.22 \\
$\mathrm{NH}_{4}^{+}$ & 0.06 & 0.23 & $\mathbf{0 . 9 6}$ & -0.02 & 0.17 & 0.02 \\
$\mathrm{Ca}^{2+}$ & 0.18 & 0.27 & -0.02 & $\mathbf{0 . 9 2}$ & 0.07 & 0.19 \\
$\mathrm{Melt}^{2}$ & -0.05 & 0.19 & 0.16 & 0.07 & $\mathbf{0 . 9 6}$ & 0.07 \\
$\mathrm{SO}_{4}^{2-}$ & 0.29 & 0.28 & 0.02 & 0.21 & 0.08 & $\mathbf{0 . 8 8}$ \\
\hline Variance explained (\%) & 38 & 19 & 11 & 11 & 11 & 10 \\
\hline
\end{tabular}

in $\mathrm{NH}_{4}^{+}$to enhanced $\mathrm{NH}_{3}$ emissions from agriculture and livestock mainly in Eurasia (Eichler et al., 2009; Weiler et al., 2005). This is in contrast to studies from North America and western Europe, where anthropogenic pollution already started rising in the second half of the nineteenth century due to an earlier industrialisation and intensification of agriculture (see e.g. Döscher et al., 1996). The anthropogenic impact is also seen in the $\mathrm{NO}_{3}^{-}$and - less pronounced - in the $\mathrm{NH}_{4}^{+}$ record of the Lomo97 core (Divine et al., 2011; Kekonen et al., 2005) (Fig. 4), which underlines the spatial representativeness of the Lomo09 ice-core data. The $\mathrm{NO}_{3}^{-}$records of the Lomo09 and Lomo97 cores agree well. This is not the case for the $\mathrm{NH}_{4}^{+}$records, where the Lomo97 shows higher concentrations, especially before 1900 (Fig. 4). We cannot explain this difference, but $\mathrm{NH}_{4}^{+}$is known to be prone to contamination during analysis (Jauhiainen et al., 1999; Kaufmann et al., 2010; Legrand et al., 1984, 1993, 1999; Udisti et al., 1994). Three observations indicate that the Lomo09 $\mathrm{NH}_{4}^{+}$ concentrations are robust: (1) the preindustrial Lomo09 values are generally lower than those of Lomo97 and therefore contamination seems unlikely; (2) the Lomo09 preindustrial ion balance is close to 0 (Fig. S2), and (3) the 300-year record of $\mathrm{NH}_{4}^{+}$from Holtedahlfonna (Beaudon et al., 2013) is in reasonable agreement with the Lomo09 data, except for the period around 1750 (Fig. 4).

In order to investigate sources of $\mathrm{NH}_{4}^{+}$and $\mathrm{NO}_{3}^{-}$and other ionic species in the Lomo09 ice core, we performed a principal component analysis (PCA). We used 10-year averages to account for dating uncertainties and smoothing effects by meltwater relocation. Previous studies on the Lomo97 core suggested that the percolation lengths at the site can reach two to eight annual layers in the warmest years (Moore et al., 2005; Pohjola et al., 2002). The average annual melt percent of the Lomo97 core was $41 \%$ (Pohjola et al., 2002) compared to $31 \%$ of the Lomo09 core. We thus assume that the maximum percolation lengths in the Lomo09 core do not exceed the eight annual layers determined for the Lomo97 core. As a conservative estimate we used the 10-year-average record of melt percent in the PCA to examine the influence of melt on the $\mathrm{NH}_{4}^{+}$and $\mathrm{NO}_{3}^{-}$records. The PCA was performed only for pre-industrial times (1222-1859) to exclude anthropogenic influences on the ion concentrations. Sulfate $\left(\mathrm{SO}_{4}^{2-}\right)$ from anthropogenic sources has been shown to increase already during the second half of the nineteenth century (Moore et al., 2006).

We obtained six principal components (PCs) from the PCA (Table 2). PC1 has high loadings of sodium $\left(\mathrm{Na}^{+}\right)$, potassium $\left(\mathrm{K}^{+}\right)$, magnesium $\left(\mathrm{Mg}^{2+}\right)$, and chloride $\left(\mathrm{Cl}^{-}\right)$. This component explains $38 \%$ of the total variance and contains species that are directly emitted by sea spray. $\mathrm{PC} 2$ has high loadings of methane sulfonate ( $\mathrm{MSA}=\mathrm{CH}_{3} \mathrm{SO}_{3}^{-}$) and $\mathrm{NO}_{3}^{-}$. MSA has a strictly marine biogenic source. It results from the oxidation of gaseous dimethyl sulfide (DMS) which is produced by phytoplankton and emitted from the ocean into the atmosphere. This gas release across the sea-air interface differs distinctly from the way sea salt species are emitted into the atmosphere via sea spray because no droplets are involved (Stefels et al., 2007; Vogt and Liss, 2009). PC3 has a high loading of $\mathrm{NH}_{4}^{+}$, representing biogenic emissions. Calcium $\left(\mathrm{Ca}^{2+}\right)$ is the only species that has a high loading in PC4. This suggests that PC4 represents a mineral dust component. The melt percent is the only parameter that has a high loading in PC5. Although we do not expect a simple correlation between melt in a particular layer and net chemical flux, this result suggests that there is at least not a net loss of the investigated major ions from layers of extreme melt, which together with the findings of Pohjola et al. (2002) and Moore et al. (2005) supports our conclusion that melt has not been of major influence on the ion concentrations on the considered decadal timescale. PC6 has a high loading of $\mathrm{SO}_{4}^{2-}$, indicating a volcanic source. We can exclude a dominant sea spray and marine biogenic influence on $\mathrm{SO}_{4}^{2-}$, due to the low loadings within PC1 and PC2, respectively. The results of the PCA are in good correspondence to those of a correlation 
Table 3. $R^{2}$ values of the correlation analysis of the ionic species and the melt percent (Melt \%). Time period: 1222-1859; data: 10-year averages; MSA: $\mathrm{CH}_{3} \mathrm{SO}_{3}^{-} ; 0.5<r^{2}<1$ marked in bold.

\begin{tabular}{lrrrrrrrrrr}
\hline$r^{2}$ & $\mathrm{Na}^{+}$ & $\mathrm{K}^{+}$ & $\mathrm{Mg}^{2+}$ & $\mathrm{Cl}^{-}$ & $\mathrm{MSA}$ & $\mathrm{NO}_{3}^{-}$ & $\mathrm{NH}_{4}^{+}$ & $\mathrm{Ca}^{2+}$ & $\mathrm{Melt} \%$ & $\mathrm{SO}_{4}^{2-}$ \\
\hline $\mathrm{Na}^{+}$ & 1 & & & & & & & & & \\
$\mathrm{~K}^{+}$ & $\mathbf{0 . 7 1}$ & 1 & & & & & & & & \\
$\mathrm{Mg}^{2+}$ & $\mathbf{0 . 7 1}$ & $\mathbf{0 . 5 9}$ & 1 & & & & & & & \\
$\mathrm{Cl}^{-}$ & $\mathbf{0 . 9 8}$ & $\mathbf{0 . 6 7}$ & $\mathbf{0 . 7 8}$ & 1 & & & & & & \\
$\mathrm{MSA}$ & 0.17 & 0.16 & 0.41 & 0.20 & 1 & & & & & \\
$\mathrm{NO}_{3}^{-}$ & 0.04 & 0.08 & 0.27 & 0.06 & $\mathbf{0 . 6 0}$ & 1 & & & & \\
$\mathrm{NH}_{4}^{+}$ & 0.01 & 0.01 & 0.03 & 0.02 & 0.14 & 0.19 & 1 & & & \\
$\mathrm{Ca}^{2+}$ & 0.09 & 0.06 & 0.27 & 0.10 & 0.26 & 0.21 & 0.00 & 1 & & \\
$\mathrm{Melt}^{2+}$ & 0.00 & 0.00 & 0.02 & 0.00 & 0.15 & 0.11 & 0.13 & 0.04 & 1 & \\
$\mathrm{SO}_{4}^{2-}$ & 0.16 & 0.18 & 0.33 & 0.17 & 0.26 & 0.26 & 0.02 & 0.24 & 0.04 & 1 \\
\hline
\end{tabular}

analysis of the 10-year-averaged records of the ionic species and the melt percent for the pre-industrial period (Table 3). Strong correlation is observed for the sea-spray-related ions $\mathrm{Na}^{+}, \mathrm{K}^{+}, \mathrm{Mg}^{2+}$, and $\mathrm{Cl}^{-}\left(0.59<r^{2}<0.98\right)$. Furthermore, MSA and $\mathrm{NO}_{3}^{-}$are highly correlated and share $60 \%$ of data variability. $\mathrm{NH}_{4}^{+}, \mathrm{Ca}^{2+}$, melt percent and $\mathrm{SO}_{4}^{2-}$ are not significantly correlated with any other species.

\subsection{Nitrate and methane sulfonate ( $\mathrm{NO}_{3}^{-}$and MSA)}

In the Arctic, MSA is well known to originate from marine biogenic sources (Legrand, 1997). However, major preindustrial $\mathrm{NO}_{3}^{-}$sources in this region are still not fully understood (e.g. Wolff et al., 2008).

Varying atmospheric MSA concentrations have been related to changing sea-ice conditions. Studies from Arctic and Antarctic ice cores found positive (Becagli et al., 2009; Legrand et al., 1997) but also negative correlations of MSA and sea-ice extent (Rhodes et al., 2009; Sharma et al., 2012); see also the review on MSA and sea ice in Antarctica by Abram et al. (2013). After 1920 the Lomo97 core MSA correlates negatively with summer (August) sea-ice extent and sea surface temperature in the Barents Sea (O'Dwyer et al., 2000) and positively with the instrumental summer temperature record from Svalbard (Isaksson et al., 2005). During the period 1600-1920 Isaksson et al. (2005) detected a positive correlation of the Lomo97 MSA and winter (April) seaice extent in the Barents Sea (Divine and Dick, 2006; Vinje, 2001). The Lomo97 MSA record reveals a pattern with twice as high values prior to about 1920 compared to those of the later twentieth century (Isaksson et al., 2005). They suggest that it results from a change of the source and/or more favourable growing conditions for the DMS-producing phytoplankton in a more extensive sea-ice environment before 1920.

In the MSA record of the Lomo09 core we find a similar pattern as in the Lomo97 core with higher concentrations prior to the twentieth century and a decreasing trend since around 1900 (Figs. 4 and 6). Hence, we investigate if a coupling of MSA with sea-ice conditions around Svalbard exists, using three long-term reconstructions of sea-ice extent. These reconstructions include the winter (April) ice extent in the western Nordic Seas covering the last 800 years (Macias Fauria et al., 2010), the summer (August) location of the sea-ice edge in the Barents Sea (BS) that covers the last 400 years (Kinnard et al., 2011), and the summer seaice extent in the Arctic seas extending back to the year 563 (Kinnard et al., 2011). The best agreement was observed between the 40-year lowpass-filtered records of Lomo09 MSA and reconstructed winter (April) western Nordic Seas ice extent (Macias Fauria et al., 2010). However, less than 50\% of the variability in the MSA record is explained by changing sea-ice conditions (Fig. 6; $r=0.56, p<0.001$ ). The most striking feature in both records is the pronounced decrease starting around 1890. This remarkable drop was also observed in the time series of the western Nordic Seas ice extent (period 1860-2000; Vinje et al., 2001), used to calibrate the proxy records (Macias Fauria et al., 2010). The strong decrease is not seen in any of the summer (August) ice records before around 1910 (Fig. 6). Furthermore, the pronounced minimum around 1710 and the peak around 1640 in the BS ice record are not reflected in the Lomo09 MSA record. Thus, our data do not support the connection of MSA at Lomonosovfonna and the BS ice extent stated in O'Dwyer et al. (2000) for the period 1920-1997, nor the assumption of Isaksson et al. (2005) that the MSA sources prior to and after 1920 were the same, i.e. the BS. We explain the positive correlation of Lomo09 MSA and western Nordic Seas ice extent as follows. The marginal ice zone is known to be the area of highest DMS production (Perrette et al., 2011). The larger the sea-ice area, the more ice edge area is available for phytoplankton growth and thus DMS production. Furthermore, more ice leads to higher freshwater inflow by melting ice. This results in a stronger stratification of the ocean water (Perrette et al., 2011) which keeps the phytoplankton in the euphotic zone. The good correspondence of the Lomo09 


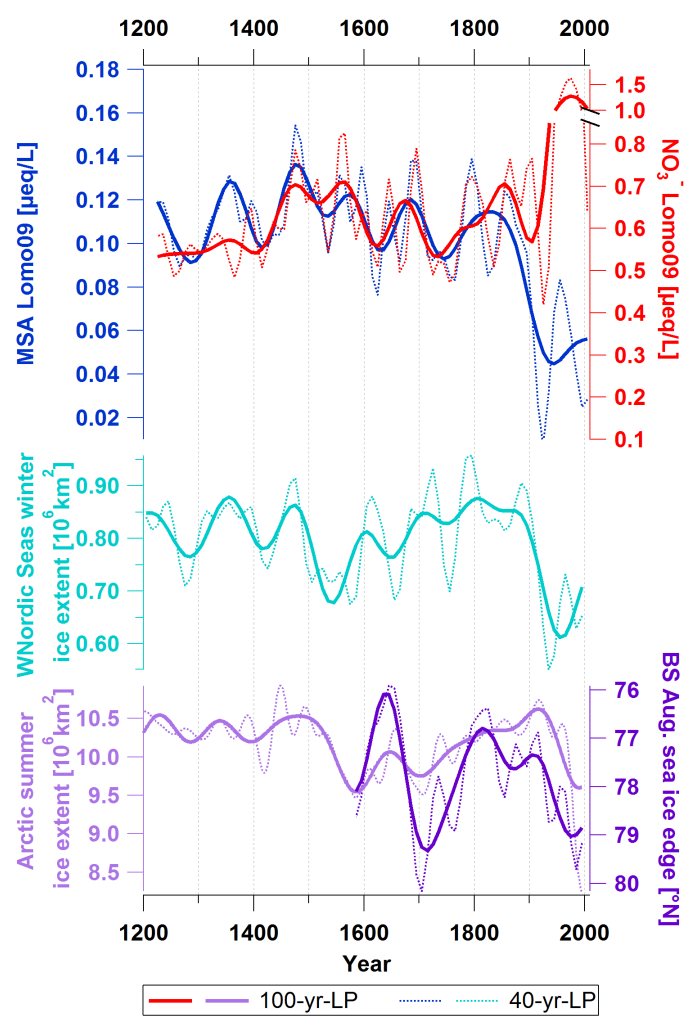

Figure 6. Records of Lomo09 MSA (dark blue), pre-industrial $\mathrm{NO}_{3}^{-}$(red), western Nordic Seas winter (April) ice extent (turquoise; Macias Fauria et al., 2010), Arctic summer (August) sea-ice extent (light purple; Kinnard et al., 2011), and August seaice edge position in the Barents Sea (BS; dark purple; Kinnard et al., 2011). Bold lines are 100-year lowpass-filtered (100-yr-LP); dashed lines are 40-year lowpass-filtered (40-yr-LP).

MSA record to the western Nordic Seas ice extent but not to that of the BS is well supported by the findings of Beaudon et al. (2013) pointing to the Greenland Sea as the main source of biogenic-related MSA in Svalbard.

In the Lomo09 ice core, MSA is highly correlated with $\mathrm{NO}_{3}^{-}$before around 1900. The records (Figs. 4 and 6) are similar, with shared peaks around 1395, 1475, 1560, 1645, 1695 , and 1795 . The only exception is the period at about 1350 when the correlation breaks down. After around 1900 there is a decoupling of both species with enhanced $\mathrm{NO}_{3}^{-}$ concentrations from anthropogenic Eurasian $\mathrm{NO}_{x}$ emissions (see above) and strongly decreased MSA concentrations.

In previous studies, $\mathrm{NO}_{3}^{-}$was found to correlate with nonsea-salt $\mathrm{Ca}^{2+}$ (nss $\mathrm{Ca}^{2+}$ ) (Legrand et al., 1999; Röthlisberger et al., 2000, 2002), suggesting that nss $\mathrm{Ca}^{2+}$ prevents $\mathrm{NO}_{3}^{-}$ from being re-emitted from the snowpack. However, those studies are from Greenland; consider glacial timescales, and include e.g. the last glacial maximum (LGM) with much higher nss- $\mathrm{Ca}^{2+}$ concentrations. Other studies observed a correlation of $\mathrm{NO}_{3}^{-}$and $\mathrm{Ca}^{2+}$ in summer and with sea salt in winter, but they considered only industrial times (Beine et al., 2003; Geng et al., 2010; Teinilä et al., 2003). The empirical orthogonal function (EOF) analysis performed on the ion data of the Lomo97 core suggests in general no correlation between $\mathrm{Ca}^{2+}$ and $\mathrm{NO}_{3}^{-}$, but in some parts of the last 200 years the two species are clearly associated (Kekonen et al., 2002). Kekonen et al. (2002) found $\mathrm{NO}_{3}^{-}$and $\mathrm{NH}_{4}^{+}$to covariate during the last 100 years. However, the EOF of the whole core did not show a clear association of $\mathrm{NH}_{4}^{+}$and $\mathrm{NO}_{3}^{-}$. Nevertheless, they suggested that before 1920 and after 1960 ammonium nitrate $\left(\mathrm{NH}_{4} \mathrm{NO}_{3}\right)$ has been common at Lomonosovfonna. They explain this in recent years to be due to Arctic haze and significant natural sources of $\mathrm{NH}_{4} \mathrm{NO}_{3}$ during the earlier period. At Holtedahlfonna, Svalbard, $\mathrm{NH}_{4}^{+}$was also associated with $\mathrm{NO}_{3}^{-}$before 1880, which Beaudon et al. (2013) interpreted as evidence of $\mathrm{NH}_{4} \mathrm{NO}_{3}$ being present. Teinilä et al. (2003) also discovered a correlation of $\mathrm{NO}_{3}^{-}$and $\mathrm{NH}_{4}^{+}$in recent times which they concluded to result from anthropogenic emissions. Our data neither support a correlation of $\mathrm{NO}_{3}^{-}$and $\mathrm{Ca}^{2+}$, nor of $\mathrm{NO}_{3}^{-}$ and the sea salt species $\mathrm{Na}^{+}$, nor of $\mathrm{NO}_{3}^{-}$and $\mathrm{NH}_{4}^{+}$in preindustrial times. Instead, they clearly suggest an association of $\mathrm{NO}_{3}^{-}$with MSA. Three hypotheses for the high correlation are discussed: (1) post-depositional processes caused by melt water percolation affecting $\mathrm{NO}_{3}^{-}$and MSA in the same way, (2) a common source of $\mathrm{NO}_{3}^{-}$and $\mathrm{MSA}$, and (3) $\mathrm{NO}_{3}^{-}$fertilisation of the ocean which triggers phytoplankton growth and thus DMS and MSA formation.

1. The pre-industrial record of the melt percent does share some features with $\mathrm{NO}_{3}^{-}$and MSA, but there is no significant correlation with $\mathrm{NO}_{3}^{-}$or MSA $\left(r^{2}=0.1\right.$ with either $\mathrm{NO}_{3}^{-}$or MSA) (Table 3, Fig. 4). This is also seen in the PCA where the melt percent and the two ionic species have their highest loadings in different PCs (Table 2). Thus, the correlation of $\mathrm{NO}_{3}^{-}$and MSA is not a result of similar relocation during melt events on the decadal timescales considered here.

2. If both species have a common source, this would have to be the ocean, because MSA results only from marine DMS production and its oxidation in the atmosphere. $\mathrm{NO}_{3}^{-}$is only a minor component in seawater, with concentrations in the micro-molar range (Chester and Jickells, 2012; Codispoti et al., 2013). The ice-core $\mathrm{NO}_{3}^{-} / \mathrm{Na}^{+}$ratio of $\sim 0.066$ in the Lomo09 core is up to a factor of 10 higher than the seawater ratio of 0.006 to 0.038 (Keene et al., 1986). Additionally, we can exclude $\mathrm{NO}_{3}^{-}$from being derived from sea spray because $\mathrm{NO}_{3}^{-}$ and the major sea spray components $\mathrm{Na}^{+}, \mathrm{K}^{+}, \mathrm{Mg}^{2+}$, and $\mathrm{Cl}^{-}$(PC1) do not correlate, as seen in the PCA and the correlation analysis (Tables 2 and 3 ). Because of the high solubility of nitrate in water, outgassing of $\mathrm{HNO}_{3}$ from the ocean is unlikely. Thus, the major $\mathrm{NO}_{3}^{-}$source is not the ocean, which excludes a common source to cause the strong correlation of $\mathrm{NO}_{3}^{-}$and MSA. 
3. Elevated atmospheric $\mathrm{NO}_{3}^{-}$concentrations due to high $\mathrm{NO}_{x}$ emissions and/or enhanced transport to the Arctic in the end of winter lead to an increased amount of $\mathrm{NO}_{3}^{-}$ dissolved in the ocean surface water. Nutrient supply in the Arctic is known to be limited and nitrate depletion is common during the vegetative season (Codispoti et al., 2013). Hence, an increased nitrogen input by dissolved $\mathrm{NO}_{3}^{-}$leads to a fertilisation of the phytoplankton (Duce et al., 2008). As soon as light becomes available this results in an enhanced production of DMS and finally higher MSA concentrations in the atmosphere. This process takes weeks to months (Codispoti et al., 2013; Sharma et al., 2012). However, such a potential short time lag cannot be resolved from our data.

We therefore propose the fertilising effect as being the dominant cause of the high correlation of $\mathrm{NO}_{3}^{-}$and MSA in pre-industrial times. In industrial times the records of $\mathrm{NO}_{3}^{-}$ and MSA diverge with increasing $\mathrm{NO}_{3}^{-}$and decreasing MSA concentrations. This reveals that during the twentieth century the effect of decreasing MSA concentrations following reduction in ice extent in the western Nordic Seas predominates compared to an expected MSA increase caused by enhanced anthropogenic $\mathrm{NO}_{3}^{-}$levels.

The major $\mathrm{NO}_{3}^{-}$source region for the industrial time is Eurasia, indicated by the similarity of the $\mathrm{NO}_{3}^{-}$records observed in the last 30-40 years in the ice cores from Lomo09, the Siberian Altai, and Severnaya Zemlya (Eichler et al., 2009; Weiler et al., 2005) (Fig. 5). We assume that the source region has not changed from pre-industrial to industrial times. In the period $1250-1940, \mathrm{NO}_{3}^{-}$in the Siberian Altai ice core was ascribed to forest fires and mineral dust as main pre-industrial sources (Eichler et al., 2011). That $\mathrm{NO}_{3}^{-}$record shows a maximum between 1540 and 1680 (see Fig. 5), attributed to an increased mineral dust input from Central Asian deserts (1540-1600) and enhanced fire activity from Siberian boreal forests (1600-1680). This distinct peak in the sixteenth and seventeenth centuries is not observed in the Lomo09 $\mathrm{NO}_{3}^{-}$record and, also, the general pre-industrial records do not correspond well. We cannot exclude the possibility that other regional-scale $\mathrm{NO}_{3}^{-}$sources in Eurasia had a significant impact on the low pre-industrial concentration level. From our data we can therefore not identify major preindustrial $\mathrm{NO}_{3}^{-}$sources for the Lomo09 core.

\subsection{Ammonium $\left(\mathrm{NH}_{4}^{+}\right)$}

The Lomo09 $\mathrm{NH}_{4}^{+}$record shows very low concentrations between the thirteenth and eighteenth centuries and an increasing trend from around 1750 onwards (Fig. 7). The values are on the same order of magnitude as those from other Arctic sites and a factor 2-3 lower compared to the Lomo97 ice core (Beaudon et al., 2013; Fuhrer et al., 1996; Kehrwald et al., 2012; Kekonen et al., 2005; Legrand and De Angelis, 1996; Legrand et al., 1992; Whitlow et al., 1994; Zen-

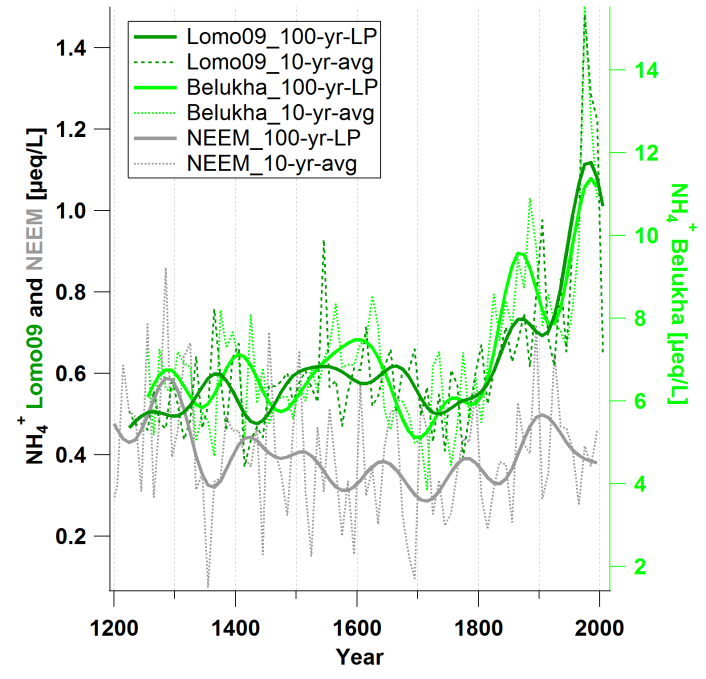

Figure 7. $\mathrm{NH}_{4}^{+}$records of the Lomo09 (green), Belukha (light green; Eichler et al., 2009), and the NEEM (grey; Zennaro et al., 2014) ice cores. Bold lines are 100-year lowpass-filtered (100-yrLP); dashed lines are the 10-year averages (10-yr-avg).

naro et al., 2014). The $\mathrm{NH}_{4}^{+}$record of another Svalbard core from Holtedahlfonna, spanning the last 300 years, shows a differing pattern prior to 1800 , but a similar strong increasing trend as the Lomo09 record from the eighteenth century on (Beaudon et al., 2013) (Fig. 4). The authors interpret the rising concentrations from 1880 as a result of anthropogenic mid-latitude pollution reaching the Arctic. However, the earlier increase in $\mathrm{NH}_{4}^{+}$concentrations in the Lomo09 and Holte 05 ice core from the eighteenth century on cannot be related to anthropogenic emissions. As discussed above, anthropogenic $\mathrm{NH}_{3}$ emissions from Eurasia influence precipitation chemistry in Svalbard only after around 1940.

Pre-industrial $\mathrm{NH}_{4}^{+}$was not studied in detail in the Lomo97 core, but Kekonen et al. (2002) suggested $\mathrm{NH}_{4} \mathrm{NO}_{3}$ to have been common at Lomonosovfonna before 1920. Similarly, Beaudon et al. (2013) postulated that at Holtedahlfonna natural $\mathrm{NH}_{4} \mathrm{NO}_{3}$ was a common aerosol. Our data do not support this hypothesis since $\mathrm{NH}_{4}^{+}$and $\mathrm{NO}_{3}^{-}$are not significantly correlated in pre-industrial times (Tables 2 and 3). In other studies pre-industrial $\mathrm{NH}_{4}^{+}$was attributed mainly to biomass burning (e.g. Fuhrer et al., 1996; Kehrwald et al., 2010; Legrand et al., 1992; Whitlow et al., 1994). North America and Canada were identified as major sources of $\mathrm{NH}_{4}^{+}$in Greenland ice (Fuhrer et al., 1996), whereas Legrand and De Angelis (1996) and Zennaro et al. (2014) suggest an additional Eurasian source. A period of exceptional high fire activity around 1600-1680 in Siberian boreal forests of Eurasia was detected in the ice core fire tracer records from the Siberian Altai and Greenland (Eichler et al., 2011; Zennaro et al., 2014). This unique period did not lead to a maximum in the Lomo09 $\mathrm{NH}_{4}^{+}$record. Therefore, we conclude 
that biomass burning is not a major source of $\mathrm{NH}_{4}^{+}$arriving at Svalbard.

The trend in the Lomo09 $\mathrm{NH}_{4}^{+}$record is similar to that in the ice core from Belukha glacier in the Siberian Altai, with increasing concentrations already from around 1750 and very low concentrations between 1680 and 1750 (Eichler et al., 2009) (Fig. 7). Before $\sim 1500, \mathrm{NH}_{4}^{+}$concentration records agree less, which could be explained by increasing dating uncertainty. At the Belukha site, long-term $\mathrm{NH}_{4}^{+}$variations were related to temperature-induced changes in biogenic $\mathrm{NH}_{3}$ emissions from extended Siberian boreal forests (Eichler et al., 2009). The strong increase after the eighteenth century was caused by a rise in Siberian temperatures since that time. Hence, from the similarity in the Lomo09 and Siberian Altai $\mathrm{NH}_{4}^{+}$concentration records, we conclude that biogenic $\mathrm{NH}_{3}$ emissions from Siberian boreal forests are the dominant source of $\mathrm{NH}_{4}^{+}$at Lomonosovfonna. Due to the larger distance to the emission sources, the $\mathrm{NH}_{4}^{+}$concentrations in the Lomo09 core are about 1 order of magnitude lower than in the core from Belukha glacier. The $\mathrm{NH}_{4}^{+}$concentrations in a Greenland ice core (NEEM; for the location, see Fig. 1) do not show the increase after the eighteenth century (Zennaro et al., 2014) (Fig. 7), implying that biogenic emission trends in North America and Eurasia differ.

\section{Summary}

We presented the 800-year records of the two nitrogen species $\mathrm{NO}_{3}^{-}$and $\mathrm{NH}_{4}^{+}$analysed in a new ice core collected from Lomonosovfonna, Svalbard, in 2009. In general, the $\mathrm{NO}_{3}^{-}$record of the 2009 ice core agrees reasonably with published data from two previous Svalbard ice cores, Lomonosovfonna 1997 (Kekonen et al., 2005) and Holtedahlfonna 2005 (Beaudon et al., 2013), whereas there is less correspondence between the different $\mathrm{NH}_{4}^{+}$records. On the decadal timescale considered here, melt-related effects did not significantly alter the concentrations of the nitrogen compounds. Both species show a clear impact of anthropogenic pollution in the twentieth century, with peak concentrations in the 1970s/1980s. This temporal trend points to source regions in Eurasia and the Siberian Arctic, since emissions in North America and western Europe kept rising into the twenty-first century. In pre-industrial times, i.e. prior to the twentieth century, the dominant source of $\mathrm{NH}_{4}^{+}$was biogenic $\mathrm{NH}_{3}$ emissions from Siberian boreal forests. During the same period, $\mathrm{NO}_{3}^{-}$was highly correlated with MSA on a decadal timescale. We explained this by a fertilising mechanism where higher atmospheric $\mathrm{NO}_{3}^{-}$concentrations yield higher nitrogen input to the ocean, triggering the growth of DMS-producing phytoplankton. Elevated DMS concentrations then result in enhanced concentrations of MSA in the atmosphere. Based on our data it was not possible to resolve major pre-industrial $\mathrm{NO}_{3}^{-}$sources for Svalbard.

\section{The Supplement related to this article is available online at doi:10.5194/acp-15-7287-2015-supplement.}

Acknowledgements. The drilling was funded by the Paul Scherrer Institut and the Norwegian Polar Institute with help from Serla.

We would like to thank B. Rufibach ${ }^{\dagger}$ and D. Stampfli for drilling; NPI field logistics personnel, M. Björkman, G. Rotschky, and C. Vega for their help during the expedition; D. Divine for the help on the sea-ice data; R. Petterson for providing the ice depth data; J. Moore for providing the Lomo97 ion data; E. Beaudon for providing the Holte05 $\mathrm{NO}_{3}^{-}$and $\mathrm{NH}_{4}^{+}$data; $\mathrm{L}$. Tobler for analysing ${ }^{210} \mathrm{~Pb}$; M. Rüthi and J. Eikenberg for analysing tritium; and A. Igesund for the help on the map in Fig. 1a.

This is a contribution to cryosphere-atmosphere interactions in a changing Arctic climate (CRAICC), a top-level research initiative (TRI).

Edited by: W. T. Sturges

\section{References}

Abram, N. J., Wolff, E. W., and Curran, M. A. J.: A review of sea ice proxy information from polar ice cores, Quaternary Sci. Rev., 79, 168-183, doi:10.1016/j.quascirev.2013.01.011, 2013.

Adams, P. J., Seinfeld, J. H., and Koch, D. M.: Global concentrations of tropospheric sulfate, nitrate, and ammonium aerosol simulated in a general circulation model, J. Geophys. Res.-Atmos., 104, 13791-13823, doi:10.1029/1999JD900083, 1999.

Baltensperger, U., Schwikowski, M., Gäggeler, H. W., Jost, D. T., Beer, J., Siegenthaler, U., Wagenbach, D., Hofmann, H. J., and Synal, H. A.: Transfer of atmospheric constituents into an alpine snow field, Atmos. Environ. A-Gen., 27, 1881-1890, doi:10.1016/0960-1686(93)90293-8, 1993.

Beaudon, E., Moore, J. C., Martma, T., Pohjola, V. A., Van De Wal, R. S. W., Kohler, J., and Isaksson, E.: Lomonosovfonna and Holtedahlfonna ice cores reveal east-west disparities of the Spitsbergen environment since AD 1700, J. Glaciol., 59, 10691083, doi:10.3189/2013JoG12J203, 2013.

Becagli, S., Castellano, E., Cerri, O., Curran, M., Frezzotti, M., Marino, F., Morganti, A., Proposito, M., Severi, M., and Traversi, R.: Methanesulphonic acid (MSA) stratigraphy from a Talos Dome ice core as a tool in depicting sea ice changes and southern atmospheric circulation over the previous 140 years, Atmos. Environ., 43, 1051-1058, 2009.

Beine, H. J., Dominè, F., Ianniello, A., Nardino, M., Allegrini, I., Teinilä, K., and Hillamo, R.: Fluxes of nitrates between snow surfaces and the atmosphere in the European high Arctic, Atmos. Chem. Phys., 3, 335-346, doi:10.5194/acp-3-335-2003, 2003.

Bergin, M. H., Jaffrezo, J.-L., Davidson, C. I., Dibb, J. E., Pandis, S. N., Hillamo, R., Maenhaut, W., Kuhns, H. D., and Makela, T.: The contributions of snow, fog, and dry deposition to the summer flux of anions and cations at Summit, Greenland, J. Geophys. Res.-Atmos., 100, 16275-16288, doi:10.1029/95JD01267, 1995.

Björkman, M. P., Kühnel, R., Partridge, D. G., Roberts, T. J., Aas, W., Mazzola, M., Viola, A., Hodson, A., Ström, J. and Isaks- 
son, E.: Nitrate dry deposition in Svalbard, Tellus B, 65, 19071, doi:10.3402/tellusb.v65i0.19071, 2013.

Brimblecombe, P., Tranter, M., Abrahams, P. W., Blackwood, I., Davies, T. D., and Vincent, C. E.: Relocation and preferential elution of acidic solute through the snowpack of a small, remote, high-altitude Scottish catchment, Ann. Glaciol., 7, 141147,1985

Chester, R. and Jickells, T. D.: Marine Geochemistry, John Wiley \& Sons, Chichester, West Sussex, UK, 2012.

Codispoti, L. A., Kelly, V., Thessen, A., Matrai, P., Suttles, S., Hill, V., Steele, M., and Light, B.: Synthesis of primary production in the Arctic Ocean: III. Nitrate and phosphate based estimates of net community production, Prog. Oceanogr., 110, 126-150, doi:10.1016/j.pocean.2012.11.006, 2013.

Dickerson, R. R.: Reactive nitrogen compounds in the Arctic, J. Geophys. Res.-Atmos., 90, 10739-10743, doi:10.1029/JD090iD06p10739, 1985.

Divine, D. V. and Dick, C.: Historical variability of sea ice edge position in the Nordic Seas, J. Geophys. Res.-Oceans, 111, C01001, doi:10.1029/2004JC002851, 2006.

Divine, D. V., Isaksson, E., Martma, T., Meijer, H. A., Moore, J., Pohjola, V., van de Wal, R. S. W., and Godtliebsen, F.: Thousand years of winter surface air temperature variations in Svalbard and northern Norway reconstructed from ice core data, Polar Res., 30, 7379, doi:10.3402/polar.v30i0.7379, 2011.

Döscher, A., Gäggeler, H. W., Schotterer, U., and Schwikowski, M.: A historical record of ammonium concentrations from a glacier in the Alps, Geophys. Res. Lett., 23, 2741-2744, 1996.

Duce, R. A., LaRoche, J., Altieri, K., Arrigo, K. R., Baker, A. R., Capone, D. G., Cornell, S., Dentener, F., Galloway, J., Ganeshram, R. S., Geider, R. J., Jickells, T., Kuypers, M. M., Langlois, R., Liss, P. S., Liu, S. M., Middelburg, J. J., Moore, C. M., Nickovic, S., Oschlies, A., Pedersen, T., Prospero, J., Schlitzer, R., Seitzinger, S., Sorensen, L. L., Uematsu, M., Ulloa, O., Voss, M., Ward, B., and Zamora, L.: Impacts of atmospheric anthropogenic nitrogen on the open ocean, Science, 320 , 893-897, doi:10.1126/science.1150369, 2008.

Eichler, A., Schwikowski, M., Gäggeler, H. W., Furrer, V., Synal, H.-A., Beer, J., Saurer, M., and Funk, M.: Glaciochemical dating of an ice core from upper Grenzgletscher (4200 ma.s.1.), J. Glaciol., 46, 507-515, doi:10.3189/172756500781833098, 2000

Eichler, A., Schwikowski, M., and Gäggeler, H. W.: Meltwaterinduced relocation of chemical species in Alpine firn, Tellus B, 53, 192-203, 2001.

Eichler, A., Brütsch, S., Olivier, S., Papina, T., and Schwikowski, M.: A 750 year ice core record of past biogenic emissions from Siberian boreal forests, Geophys. Res. Lett., 36, L18813, doi:10.1029/2009GL038807, 2009.

Eichler, A., Tinner, W., Brütsch, S., Olivier, S., Papina, T., and Schwikowski, M.: An ice-core based history of Siberian forest fires since AD 1250, Quaternary Sci. Rev., 30, 1027-1034, doi:10.1016/j.quascirev.2011.02.007, 2011.

Eleftheriadis, K., Vratolis, S., and Nyeki, S.: Aerosol black carbon in the European Arctic: measurements at Zeppelin station, Ny-Ålesund, Svalbard from 1998-2007, Geophys. Res. Lett., 36, L02809, doi:10.1029/2008GL035741, 2009.

Eneroth, K., Kjellström, E., and Holmén, K.: A trajectory climatology for Svalbard; investigating how atmospheric flow patterns influence observed tracer concentrations, Phys. Chem. Earth, 28, 1191-1203, 2003.

Feng, Y. and Penner, J. E.: Global modeling of nitrate and ammonium: Interaction of aerosols and tropospheric chemistry, J. Geophys. Res.-Atmos., 112, D01304, doi:10.1029/2005JD006404, 2007.

Fibiger, D. L., Hastings, M. G., Dibb, J. E., and Huey, L. G.: The preservation of atmospheric nitrate in snow at Summit, Greenland, Geophys. Res. Lett., 40, 3484-3489, doi:10.1002/grl.50659, 2013.

Fischer, H., Wagenbach, D., and Kipfstuhl, J.: Sulfate and nitrate firn concentrations on the Greenland ice sheet: 2 . Temporal anthropogenic deposition changes, J. Geophys. Res.-Atmos., 103, 21935-21942, doi:10.1029/98JD01886, 1998.

Forsström, S., Ström, J., Pedersen, C. A., Isaksson, E., and Gerland, S.: Elemental carbon distribution in Svalbard snow, J. Geophys. Res.-Atmos., 114, D19112, doi:10.1029/2008JD011480, 2009.

Fuhrer, K., Neftel, A., Anklin, M., Staffelbach, T., and Legrand, M.: High-resolution ammonium ice core record covering a complete glacial-interglacial cycle, J. Geophys. Res.-Atmos., 101, 41474164, doi:10.1029/95JD02903, 1996.

Galloway, J. N., Dentener, F. J., Capone, D. G., Boyer, E. W., Howarth, R. W., Seitzinger, S. P., Asner, G. P., Cleveland, C. C., Green, P. A., Holland, E. A., Karl, D. M., Michaels, A. F., Porter, J. H., Townsend, A. R., and Vöosmarty, C. J.: Nitrogen cycles: Past, present, and future, Biogeochemistry, 70, 153-226, doi:10.1007/s10533-004-0370-0, 2004.

Geng, H., Ryu, J. Y., Jung, H. J., Chung, H., Ahn, K. H., and Ro, C. U.: Single-particle characterization of summertime Arctic aerosols collected at Ny-Ålesund, Svalbard, Environ. Sci. Technol., 44, 2348-2353, 2010.

Geng, L., Alexander, B., Cole-Dai, J., Steig, E. J., Savarino, J., Sofen, E. D., and Schauer, A. J.: Nitrogen isotopes in ice core nitrate linked to anthropogenic atmospheric acidity change, P. Natl. Acad. Sci. USA, 111, 5808-5812, doi:10.1073/pnas.1319441111, 2014.

Ginot, P., Stampfli, F., Stampfli, D., Schwikowski, M., and Gäggeler, H. W.: FELICS, a new ice core drilling system for high-altitude glaciers, Mem. Natl. Inst. Polar Res. Spec. Issue, 56, 38-48, 2002.

Ginot, P., Schotterer, U., Stichler, W., Godoi, M. A., Francou, B., and Schwikowski, M.: Influence of the Tungurahua eruption on the ice core records of Chimborazo, Ecuador, The Cryosphere, 4, 561-568, doi:10.5194/tc-4-561-2010, 2010.

Goto-Azuma, K. and Koerner, R. M.: Ice core studies of anthropogenic sulfate and nitrate trends in the Arctic, J. Geophys. Res., 106, 4959-4969, 2001.

Greenaway, K. R.: Experience with Arctic flying weather, Royal Meteorological Society, Canadian Branch, Toronto, Canada, 1950.

Hastings, M. G., Steig, E. J., and Sigman, D. M.: Seasonal variations in $\mathrm{N}$ and $\mathrm{O}$ isotopes of nitrate in snow at Summit, Greenland: Implications for the study of nitrate in snow and ice cores, J. Geophys. Res.-Atmos., 109, 1984-2012, 2004.

Henderson, K., Laube, A., Gäggeler, H. W., Olivier, S., Papina, T., and Schwikowski, M.: Temporal variations of accumulation and temperature during the past two centuries from Belukha ice core, Siberian Altai, J. Geophys. Res., 111, D03104, doi:10.1029/2005JD005819, 2006. 
Hicks, S. and Isaksson, E.: Assessing source areas of pollutants from studies of fly ash, charcoal, and pollen from Svalbard snow and ice, J. Geophys. Res.-Atmos., 111, D02113, doi:10.1029/2005JD006167, 2006.

Hirdman, D., Sodemann, H., Eckhardt, S., Burkhart, J. F., Jefferson, A., Mefford, T., Quinn, P. K., Sharma, S., Ström, J., and Stohl, A.: Source identification of short-lived air pollutants in the Arctic using statistical analysis of measurement data and particle dispersion model output, Atmos. Chem. Phys., 10, 669-693, doi:10.5194/acp-10-669-2010, 2010a.

Hirdman, D., Burkhart, J. F., Sodemann, H., Eckhardt, S., Jefferson, A., Quinn, P. K., Sharma, S., Ström, J., and Stohl, A.: Longterm trends of black carbon and sulphate aerosol in the Arctic: changes in atmospheric transport and source region emissions, Atmos. Chem. Phys., 10, 9351-9368, doi:10.5194/acp-10-93512010, 2010b.

Honrath, R. E., Peterson, M. C., Guo, S., Dibb, J. E., Shepson, P. B., and Campbell, B.: Evidence of $\mathrm{NO}_{x}$ production within or upon ice particles in the Greenland snowpack, Geophys. Res. Lett., 26, 695-698, doi:10.1029/1999GL900077, 1999.

Isaksson, E., Pohjola, V., Jauhiainen, T., Moore, J., Pinglot, J. F., Vaikmaae, R., van de Wal, R. S. W., Hagen, J. O., Ivask, J., Karlöf, L., Martma, T., Meijer, H. A., Mulvaney, R., Thomassen, M., and van den Broeke, M.: A new ice-core record from Lomonosovfonna, Svalbard: viewing the 1920-97 data in relation to present climate and environmental conditions, J. Glaciol., 47, 335-345, 2001.

Isaksson, E., Kekonen, T., Moore, J., and Mulvaney, R.: The methanesulfonic acid (MSA) record in a Svalbard ice core, Ann. Glaciol., 42, 345-351, 2005.

Jauhiainen, T., Moore, J., Perämäki, P., Derome, J., and Derome, K.: Simple procedure for ion chromatographic determination of anions and cations at trace levels in ice core samples, Anal. Chim. Acta, 389, 21-29, 1999.

Kaufmann, P., Fundel, F., Fischer, H., Bigler, M., Ruth, U., Udisti, R., Hansson, M., de Angelis, M., Barbante, C., Wolff, E. W., Hutterli, M., and Wagenbach, D.: Ammonium and non-sea salt sulfate in the EPICA ice cores as indicator of biological activity in the Southern Ocean, Quaternary Sci. Rev., 29, 313-323, doi:10.1016/j.quascirev.2009.11.009, 2010.

Keene, W. C., Pszenny, A. A. P., Galloway, J. N., and Hawley, M. E.: Sea-salt corrections and interpretation of constituent ratios in marine precipitation, J. Geophys. Res.-Atmos., 91, 6647-6658, doi:10.1029/JD091iD06p06647, 1986.

Kehrwald, N., Zangrando, R., Gambaro, A., and Barbante, C.: Fire and climate: Biomass burning recorded in ice and lake cores, EPJ Web Conf., 9, 105-114, doi:10.1051/epjconf/201009008, 2010.

Kehrwald, N., Zangrando, R., Gabrielli, P., Jaffrezo, J.-L., Boutron, C., Barbante, C., and Gambaro, A.: Levoglucosan as a specific marker of fire events in Greenland snow, Tellus B, 64, 18196, doi:10.3402/tellusb.v64i0.18196, 2012.

Kekonen, T., Moore, J. C., Mulvaney, R., Isaksson, E., Pohjola, V., and Van De Wal, R. S. W.: A 800 year record of nitrate from the Lomonosovfonna ice core, Svalbard, Ann. Glaciol., 35, 261-265, 2002.

Kekonen, T., Moore, J., Perämäki, P., Mulvaney, R., Isaksson, E., Pohjola, V., and van de Wal, R. S. W.: The 800 year long ion record from the Lomonosovfonna (Svalbard) ice core, J. Geophys. Res., 110, D07304, doi:10.1029/2004JD005223, 2005.
Kellerhals, T., Brütsch, S., Sigl, M., Knüsel, S., Gäggeler, H. W., and Schwikowski, M.: Ammonium concentration in ice cores: A new proxy for regional temperature reconstruction?, J. Geophys Res.-Atmos., 115, D16123, doi:10.1029/2009JD012603, 2010.

Kinnard, C., Zdanowicz, C. M., Fisher, D. A., Isaksson, E., de Vernal, A., and Thompson, L. G.: Reconstructed changes in Arctic sea ice over the past 1450 years, Nature, 479, 509-512, 2011.

Kühnel, R., Roberts, T. J., Björkman, M. P., Isaksson, E., Aas, W., Holmén, K., and Ström, J.: 20-year climatology of $\mathrm{NO}_{3}^{-}$and $\mathrm{NH}_{4}^{+}$wet deposition at $\mathrm{Ny}$-Ålesund, Svalbard, Adv. Meteorol., 406508, doi:10.1155/2011/406508, 2011.

Lavigne, F., Degeai, J.-P., Komorowski, J.-C., Guillet, S., Robert, V., Lahitte, P., Oppenheimer, C., Stoffel, M., Vidal, C. M., Surono, Pratomo, I., Wassmer, P., Hajdas, I., Hadmoko, D. S., and Belizal, E. de: Source of the great A.D. 1257 mystery eruption unveiled, Samalas volcano, Rinjani Volcanic Complex, Indonesia, P. Natl. Acad. Sci. USA, 110, 16742-16747, doi:10.1073/pnas.1307520110, 2013.

Law, K. S. and Stohl, A.: Arctic air pollution: Origins and impacts, Science, 315, 1537-1540, 2007.

Legrand, M.: Ice-core records of atmospheric sulphur, Philos. T. Roy. Soc. B, 352, 241-250, 1997.

Legrand, M. and De Angelis, M.: Light carboxylic acids in Greenland ice: A record of past forest fires and vegetation emissions from the boreal zone, J. Geophys. Res.-Atmos., 101, 4129-4145, 1996.

Legrand, M. and Mayewski, P.: Glaciochemistry of polar ice cores: a review, Rev. Geophys., 35, 219-244, 1997.

Legrand, M., de Angelis, M., and Delmas, R. J.: Ion chromatographic determination of common ions at ultratrace levels in Antarctic snow and ice, Anal. Chim. Acta, 156, 181-192, doi:10.1016/S0003-2670(00)85549-X, 1984.

Legrand, M., De Angelis, M., Staffelbach, T., Neftel, A., and Stauffer, B.: Large perturbations of ammonium and organic acids content in the summit-Greenland Ice Core. Fingerprint from forest fires?, Geophys. Res. Lett., 19, 473-475, doi:10.1029/91GL03121, 1992.

Legrand, M., De Angelis, M., and Maupetit, F.: Field investigation of major and minor ions along Summit (Central Greenland) ice cores by ion chromatography, J. Chromatogr. A, 640, 251-258, doi:10.1016/0021-9673(93)80188-E, 1993.

Legrand, M., Hammer, C., Angelis, M. D., Savarino, J., Delmas, R., Clausen, H., and Johnsen, S. J.: Sulfur-containing species (methanesulfonate and $\mathrm{SO}_{4}$ ) over the last climatic cycle in the Greenland Ice Core Project (central Greenland) ice core, J. Geophys. Res., 102, 26663-26679, doi:10.1029/97JC01436, 1997.

Legrand, M., Wolff, E., and Wagenbach, D.: Antarctic aerosol and snowfall chemistry: implications for deep Antarctic ice-core chemistry, Ann. Glaciol., 29, 66-72, doi:10.3189/172756499781821094, 1999.

Macias Fauria, M., Grinsted, A., Helama, S., Moore, J., Timonen, M., Martma, T., Isaksson, E., and Eronen, M.: Unprecedented low twentieth century winter sea ice extent in the Western Nordic Seas since AD 1200, Clim. Dyn., 34, 781-795, 2010.

Matoba, S., Narita, H., Motoyama, H., Kamiyama, K., and Watanabe, O.: Ice core chemistry of Vestfonna ice cap in Svalbard, Norway, J. Geophys. Res., 107, 4721, doi:10.1029/2002JD002205, 2002. 
Moore, J. C. and Grinsted, A.: Ion Fractionation and Percolation in Ice Cores with Seasonal Melting, in Physics of Ice Core Records II, vol. 68, Institute of Low Temperature Science, Hokkaido University, Hokkaido University Press, Sapporo, Japan, 287-298, 2009.

Moore, J. C., Grinsted, A., Kekonen, T., and Pohjola, V.: Separation of melting and environmental signals in an ice core with seasonal melt, Geophys. Res. Lett., 32, L10501, doi:10.1029/2005GL023039, 2005.

Moore, J., Kekonen, T., Grinsted, A., and Isaksson, E.: Sulfate source inventories from a Svalbard ice core record spanning the Industrial Revolution, J. Geophys. Res., 111, D15307, doi:10.1029/2005JD006453, 2006.

Moore, J. C., Beaudon, E., Kang, S., Divine, D., Isaksson, E., Pohjola, V. A., and van de Wal, R. S. W.: Statistical extraction of volcanic sulphate from nonpolar ice cores, J. Geophys. Res., 117, D03306, doi:10.1029/2011JD016592, 2012.

O’Dwyer, J., Isaksson, E., Vinje, T., Jauhiainen, T., Moore, J., Pohjola, V., Vaikmae, R., and van de Wal, R. S. W.: Methanesulfonic acid in a Svalbard ice core as an indicator of ocean climate, Geophys. Res. Lett., 27, 1159-1162, 2000.

Opel, T., Fritzsche, D., and Meyer, H.: Eurasian Arctic climate over the past millennium as recorded in the Akademii Nauk ice core (Severnaya Zemlya), Clim. Past, 9, 2379-2389, doi:10.5194/cp9-2379-2013, 2013.

Perrette, M., Yool, A., Quartly, G. D., and Popova, E. E.: Nearubiquity of ice-edge blooms in the Arctic, Biogeosciences, 8, 515-524, doi:10.5194/bg-8-515-2011, 2011.

Pohjola, V. A., Moore, J. C., Isaksson, E., Jauhiainen, T., Van de Wal, R. S. W., Martma, T., Meijer, H. A. J., and Vaikmäe, R.: Effect of periodic melting on geochemical and isotopic signals in an ice core from Lomonosovfonna, Svalbard, J. Geophys. Res., 107, ACL 1-1-ACL 1-14, doi:10.1029/2000JD000149, 2002.

Quinn, P. K., Shaw, G., Andrews, E., Dutton, E. G., Ruoho-Airola, T., and Gong, S. L.: Arctic haze: current trends and knowledge gaps, Tellus B, 59, 99-114, 2007.

Rhodes, R. H., Bertler, N. A. N., Baker, J. A., Sneed, S. B., Oerter, H., and Arrigo, K. R.: Sea ice variability and primary productivity in the Ross Sea, Antarctica, from methylsulphonate snow record, Geophys. Res. Lett., 36, L10704, doi:10.1029/2009GL037311, 2009.

Röthlisberger, R., Hutterli, M. A., Sommer, S., Wolff, E. W., and Mulvaney, R.: Factors controlling nitrate in ice cores: Evidence from the Dome C deep ice core, J. Geophys. Res.-Atmos., 105, 20565-20572, doi:10.1029/2000JD900264, 2000.

Röthlisberger, R., Hutterli, M. A., Wolff, E. W., Mulvaney, R., Fischer, H., Bigler, M., Goto-Azuma, K., Hansson, M. E., Ruth, U., Siggaard-Andersen, M.-L., and Steffensen, J. P.: Nitrate in Greenland and Antarctic ice cores: a detailed description of post-depositional processes, Ann. Glaciol., 35, 209-216, doi:10.3189/172756402781817220, 2002.

Samuelsson, H.: Distribution of melt layers on the ice field Lomonosovfonna, Spitsbergen, Master thesis, Uppsala University, Uppsala, Sweden, 2001.

Sharma, S., Chan, E., Ishizawa, M., Toom-Sauntry, D., Gong, S. L., Li, S. M., Tarasick, D. W., Leaitch, W. R., Norman, A., Quinn, P. K., Bates, T. S., Levasseur, M., Barrie, L. A., and Maenhaut, W.: Influence of transport and ocean ice extent on biogenic aerosol sulfur in the Arctic atmosphere, J. Geophys. Res., 117, D12209, doi:10.1029/2011JD017074, 2012.

Shaw, G. E.: The arctic haze phenomenon, B. Am. Meteorol. Soc., 76, 2403-2414, 1995.

Sigl, M.: Ice core based reconstruction of past climate conditions from Colle Gnifetti, Swiss Alps, PhD thesis, University of Bern, Bern, Switzerland, 2009.

Sigl, M., McConnell, J. R., Layman, L., Maselli, O., McGwire, K., Pasteris, D., Dahl-Jensen, D., Steffensen, J. P., Vinther, B., Edwards, R., Mulvaney, R., and Kipfstuhl, S.: A new bipolar ice core record of volcanism from WAIS Divide and NEEM and implications for climate forcing of the last 2000 years, J. Geophys. Res.-Atmos., 118, 1151-1169, doi:10.1029/2012JD018603, 2013.

Simões, J. C. and Zagorodnov, V. S.: The record of anthropogenic pollution in snow and ice in Svalbard, Norway, Atmos. Environ., 35, 403-413, 2001.

Stefels, J., Steinke, M., Turner, S., Malin, G., and Belviso, S.: Environmental constraints on the production and removal of the climatically active gas dimethylsulphide (DMS) and implications for ecosystem modelling, Biogeochemistry, 83, 245-275, doi:10.1007/s10533-007-9091-5, 2007.

Stohl, A.: Characteristics of atmospheric transport into the Arctic troposphere, J. Geophys. Res., 111, D11306, doi:10.1029/2005JD006888, 2006.

Stohl, A., Berg, T., Burkhart, J. F., Fjæraa, A. M., Forster, C., Herber, A., Hov, Ø., Lunder, C., McMillan, W. W., Oltmans, S., Shiobara, M., Simpson, D., Solberg, S., Stebel, K., Ström, J., Tørseth, K., Treffeisen, R., Virkkunen, K., and Yttri, K. E.: Arctic smoke - record high air pollution levels in the European Arctic due to agricultural fires in Eastern Europe in spring 2006, Atmos. Chem. Phys., 7, 511-534, doi:10.5194/acp-7-511-2007, 2007.

Teinilä, K., Hillamo, R., Kerminen, V.-M., and Beine, H. J.: Aerosol chemistry during the NICE dark and light campaigns, Atmos. Environ., 37, 563-575, doi:10.1016/S1352-2310(02)00826-9, 2003.

Thompson, L. G., Davis, M. E., Mosley-Thompson, E., Sowers, T. A., Henderson, K. A., Zagorodnov, V. S., Lin, P.-N., Mikhalenko, V. N., Campen, R. K., Bolzan, J. F., Cole-Dai, J., and Francou, B.: A 25000 -year tropical climate history from Bolivian ice cores, Science, 282, 1858-1864, doi:10.1126/science.282.5395.1858, 1998.

Tunved, P., Ström, J., and Krejci, R.: Arctic aerosol life cycle: linking aerosol size distributions observed between 2000 and 2010 with air mass transport and precipitation at Zeppelin station, Ny-Ålesund, Svalbard, Atmos. Chem. Phys., 13, 3643-3660, doi:10.5194/acp-13-3643-2013, 2013.

Udisti, R., Bellandi, S., and Piccardi, G.: Analysis of snow from Antarctica: a critical approach to ionchromatographic methods, Fresen. J. Anal. Chem., 349, 289-293, doi:10.1007/BF00323205, 1994.

Van De Wal, R. S. W., Mulvaney, R., Isaksson, E., Moore, J. C., Pinglot, J. F., Pohjola, V. A., and Thomassen, M. P. A.: Reconstruction of the historical temperature trend from measurements in a medium-length borehole on the Lomonosovfonna plateau, Svalbard, Ann. Glaciol., 35, 371-378, 2002.

Vinje, T.: Anomalies and trends of sea-ice extent and atmospheric circulation in the Nordic seas during the period 1864-1998, J. Climate, 14, 255-267, 2001. 
Vogt, M. and Liss, P. S.: Dimethylsulfide and Climate, in Surface Ocean-Lower Atmosphere Processes, edited by: Quéré, C. L. and Saltzman, E. S., American Geophysical Union, Washington, D. C., 197-232, doi:10.1029/2008GM000790, 2009.

Weiler, K., Fischer, H., Fritzsche, D., Ruth, U., Wilhelms, F., and Miller, H.: Glaciochemical reconnaissance of a new ice core from Severnaya Zemlya, Eurasian Arctic, J. Glaciol., 51, 64-74, doi:10.3189/172756505781829629, 2005.

Whitlow, S., Mayewski, P., Dibb, J., Holdsworth, G., and Twickler, M.: An ice-core-based record of biomass burning in the Arctic and Subarctic, 1750-1980, Tellus B, 46, 234-242, 1994.
Wolff, E. W.: Ice sheets and nitrogen, Philos. T. Roy. Soc. B, 368, 20130127, doi:10.1098/rstb.2013.0127, 2013.

Wolff, E. W., Jones, A. E., Bauguitte, S. J.-B., and Salmon, R. A.: The interpretation of spikes and trends in concentration of nitrate in polar ice cores, based on evidence from snow and atmospheric measurements, Atmos. Chem. Phys., 8, 5627-5634, doi:10.5194/acp-8-5627-2008, 2008.

Zennaro, P., Kehrwald, N., McConnell, J. R., Schüpbach, S., Maselli, O. J., Marlon, J., Vallelonga, P., Leuenberger, D., Zangrando, R., Spolaor, A., Borrotti, M., Barbaro, E., Gambaro, A., and Barbante, C.: Fire in ice: two millennia of boreal forest fire history from the Greenland NEEM ice core, Clim. Past, 10, 1905-1924, doi:10.5194/cp-10-1905-2014, 2014. 